\title{
Agro-Meteorological Indices for Soybean Crop under Different Growing Environment
}

\author{
A.P. Karunakar*, M.B. Nagdeve, A.B. Turkhede and R.S. Mali
}

All India Co-ordinated Research Project for Dryland Agriculture (Agrometeorology), Dr. Panjabrao Deshmukh Krishi Vidyapeeth, Akola (MS) - 444104, India

*Corresponding author

\begin{tabular}{|c|}
\hline Keywords \\
\hline $\begin{array}{l}\text { Growing degree days, } \\
\text { Heat thermal unit, Photo } \\
\text { thermal units, Heat use } \\
\text { efficiency, Productivity }\end{array}$ \\
\hline Article Info \\
\hline $\begin{array}{l}\text { Accepted: } \\
\text { 26 July } 2018 \\
\text { Available Online: } \\
10 \text { August } 2018\end{array}$ \\
\hline
\end{tabular}

\section{Introduction}

Soybean (Glycine max (L.) Merill.) is one of the leguminous pulse and oil seed crops in the tropical and sub-tropical regions. It is an industrial crop, cultivated for oil and protein. Despite the relatively low oil content of the seed (about $20 \%$ on moisture free basis), soybean crop is the largest single source of edible oil and account for 59 per cent of the world's production. Other key benefit are
Soybean, among the major crop of the region, is one of the classical short day plants and faces thermo-sensitivity in nature. The crop growing environmental conditions can be manipulated by opting different sowing dates resulting in different sets of environmental conditions for the crop, which are likely to be encountered during crop growth. An experiment was conducted during the kharif season of 2016-17 at the field of All India Coordinated Research Project on Agro-meteorology, Dr. Panjabrao Deshmukh Krishi Vidyapeeth, Akola (MS).Four sowing times $26^{\text {th }}, 27^{\text {th }}, 28^{\text {th }}$ and $29^{\text {th }}$ MW and three soybean genotypes JS-335, JS-9305 and TAMS-98-21 were tested in FRBD with three replications. Results revealed that, soybean sown during $26^{\text {th }}$ MW recorded significantly higher seed yield with maximum heat use efficiency and water use efficiency. Soybean variety JS 335recorded significantly higher seed yield with maximum heat use efficiency and water use efficiency. Pod formation to seed filling stage is the most important for determining the quantity of seed yield. During these stages, minimum temperature, rainfall and relative humidity (RH I \& II) showed a positive and significant association with the seed yield. Increased maximum temperature and diurnal temperature range and inadequate rainfall at the growth stage of beginning seed, has the greatest impact on soybean yield. Optimum rainfall and temperatures encountered during the critical reproductive phase (PF-SF) of earlier planted soybean crop favoured higher seed yield levels.

related to its excellent protein content of about $40 \%$ (content all essential amino acids), high levels of essential fatty acids, numerous vitamins and minerals, isoflavones and fibre. Most of the soy products act as perfect replacements for meat and dairy products specially required for vegetarians.

In India it is largely grown in Madhya Pradesh and Maharashtra. The area covered under soybean crops in India is 108.366 lakh hectare 
having production of 104.366 lakh million tonnes with productivity of $959 \mathrm{~kg} \mathrm{ha}^{-1}$. Whereas, in Maharashtra the area under cultivation is 38.008 lakh ha having production of 30.721 lakh million tonnes with productivity of $808 \mathrm{~kg} \mathrm{ha}^{-1}$. In Vidarbha, area under soybean is 19.31 lakh ha having production of 14.76 lakh millions tonnes with productivity of $776 \mathrm{~kg} \mathrm{ha}^{-1}$. In Akola, area under soybean is 2.331 lakh ha having production of 1.632lakh million tonnes with productivity of $700 \mathrm{~kg} \mathrm{ha}^{-1}$. Madhya Pradesh is leading with 58.12 lakh ha area under soybean having production of 60.249 lakh million tonnes with productivity of $1086 \mathrm{Kg} \mathrm{ha}^{-1}$ (www.sopa.org, 2014).

Crop growth and development are the functions of energy receipt and thermal regime in any given crop growth season. Soybean, among the major crop of the region, is one of the classical short day plants and faces thermo-sensitivity in nature. The crop growing environmental conditions can be manipulated by opting different sowing dates resulting in different sets of environmental conditions for the crop, which are likely to be encountered during crop growth. Sowing dates depict varied performance and productivity due to changed environment-plant interactions. In order to know the response of a crop to the weather it has availed during each phenophase, it is necessary to have the information justifying the responses in terms of phenotypic plasticity as well as yield of crop. With objectives quantification of crop growing environment in terms of the natural weather resource availed by the crop in different phenophase, so as to know crop response in terms of phenology, heat units availed, yield and heat use efficiency.

\section{Materials and Methods}

A field experiment was carried out at the field of All India Coordinated Research Project on
Dryland Agriculture, Dr. Panjabrao Deshmukh Krishi Vidyapeeth, Akola (MS) during Kharif season of 2015-16. Four sowing time 26, 27, 28 and $29 \mathrm{MW}$ and three soybean genotypes JS-335, JS-9305 and TAMS-98-21 were laid out in Factorial Randomized Block Design with three replications. Soil of experimental plot was medium deep black.

Soybean genotypes were sown as per treatments. Growing degree days, heliothermal units, photo-thermal unit, day length hours, heat use efficiency and water use indices calculated by the following formulas:

\section{Growing degree days}

Growing degree days for all treatments were calculated form daily weather data on maximum and minimum temperature as under

$\mathrm{GDD}=\left(\sum T \max +{ }^{\sum T \min } / 2\right)-$ Tbase

Where,

T base- base temperature as $10^{\circ} \mathrm{C}$

Tmax- maximum temperature

$\mathrm{T}$ min- minimum temperature

\section{Heliothermal units}

Heliothermal units, the product of GDD and corresponding actual sunshine hours (SS) for that day were computed on daily basis from date of sowing to particular date of phenophase and from that accumulated HTU for each phenophase and total HTU over the crop period in each treatment.

HTU $\left({ }^{0} \mathrm{C}\right.$ day hour $)=\Sigma(G D D x B S H)$

\section{Photothermal units}

It is calculated by the product of GDD and corresponding day length for that day on daily basis as follows: 
PTU $\left({ }^{0} \mathrm{C}\right.$ day hr $)=$ GDD $x$ Day Length

\section{Thermal use efficiency}

Thermal use efficiency in terms of seed and biomass yield was computed treatment wise by dividing the seed yield and biomass yield of soybean by corresponding accumulated thermal units (GDD) of the treatment.

TUE $=\{$ Seed yield $/$ Biological yield $(\mathrm{kg}$ ha

$\left.\left.{ }^{1}\right)\right\} /$ Accumulated thermal units $\left({ }^{0} \mathrm{C}\right.$ day $)$

\section{Crop water productivity}

Crop water productivity based on actual evapotranspiration is defined as Crop yield/ Water consumptively used in ET i.e actual crop water use (Kassam and Smith, 2001) calculated as below:

$\mathrm{CWP}=\mathrm{Yc} / \mathrm{Eta}$

Where,

CWP- Crop water productivity $\mathrm{kg}$ (ha-mm $)^{-1}$ Yc- Crop yield $\left(\mathrm{kg}^{-1}\right)$

Eta- Actual crop evapotranspiration (mm).

\section{Results and Discussion}

\section{Rainfall Distribution}

Rainfall distribution among various phenophase of soybean cultivars under different sowing dates is presented in Table 1. Overall, crop sown during $26 \mathrm{MW}$ (28 June) received higher amount of rainfall $(662.8 \mathrm{~mm})$ during the total growing period, which decreased with each delayed sowing date. Rainfall across the growing period (emergence to physiological maturity) did not vary markedly in the first two sowings - $\mathrm{D}_{1}(662.8$ $\mathrm{mm}), \mathrm{D}_{2}(628.5 \mathrm{~mm})$. Also it was more or less similar in the last two sowings $\mathrm{D}_{3}(422.6 \mathrm{~mm})$ and $\mathrm{D}_{4}(414.4 \mathrm{~mm})$. In terms of total rainfall, during vegetative and reproductive stages : $D_{1}$, $\mathrm{D}_{2}, \mathrm{D}_{3}$ and $\mathrm{D}_{4}$ sowing received $492.7 \mathrm{~mm}$, $420.9 \mathrm{~mm}, 189.8 \mathrm{~mm}$ and $194.2 \mathrm{~mm}$ of the total amount of rainfall up to true vegetative phase. During flowering phase, the crop encountered comparatively very lesser amount of rainfall in all sowings. Besides the differential morpho-physiological response of the crop to sowing time, subdued/ sub-optimal rainfall activity and consequent suboptimal soil moisture across the pod formation to seed development phase is a common feature in the region under later sowings as compared to earlier sowing.

Deviating from the normal feature, during 2016 across the period from pod formation to full seed development rainfall was quantitatively more with later sowings. $\mathrm{D}_{1}, \mathrm{D}_{2}$, $\mathrm{D}_{3}$ and $\mathrm{D}_{4}$ sowings received 128.4, 146.6, 181.3 and $194.1 \mathrm{~mm}$ rainfall, respectively. In the present study earlier sown crop received fairly adequate amount and distribution of rainfall across the critical growing period. By and large in the later sowings, decrease amount of rainfall at the respective stages might have a progressive and cumulative inadequacy effect carried across the growing period till seed development stage.

Total rainfall received during the crop growing period and also phenophase wise the rainfall amount did not vary much among the varieties- JS-335 $(526.7 \mathrm{~mm})$, JS 9305 (520.8 $\mathrm{mm})$ and TAMS-98-21 (548.7 $\mathrm{mm})$. Slight variations observed among the rainfall amount across the phenophase of the varieties was due to differences in duration of respective variety being slightly more under TAMS-98-21 as compare to JS-9305 and JS-335.

\section{Growing degree days (GDD)}

The growing degree days were computed by considering the base temperature of $10.0{ }^{\circ} \mathrm{C}$ for soybean crop. The sum of growing degree 
days $\left({ }^{0} \mathrm{C}\right.$ day) for each phenophase across the crop growing period is presented in Tables 2.The accumulated growing degree days to reach various growth stages showed variation among the dates of sowing and cultivars. The accumulated growing degree days were reasonably higher during reproductive stage (flowering to full seed development stage) as compared to vegetative stage.

Across the reproductive phenophase, seed formation to seed development phase cumulatively availed higher growing degree days (Table 2). Sowing of $26 \mathrm{MW}$ accumulated highest growing degree days $\left(1653{ }^{0} \mathrm{C}\right.$ day) to reach various phenophase which decreased with successive later sowings.

Singh and Arya (1994), Dhingra et al., (1995) and Agarwal and Gupta (1996) reported that total dry matter yield and its portioning to different components was also drastically reduced with delay in sowing. Similar findings were also recorded by Medidia et al., (2006) and Anil Kumar et al., (2008), reported that GDD consumed by the crop to reach physiological maturity was higher in the first date of sown crop i.e. $30^{\text {th }}$ May.

Among the cultivars the highest growing degree days were accumulated by TAMS-98$21\left(1624{ }^{\circ} \mathrm{C}\right.$ day $)$ followed by JS-335 $\left(1568{ }^{\circ} \mathrm{C}\right.$ day) and JS-9305 (1523 ${ }^{0} \mathrm{C}$ day). Accumulation of higher growing degree days was due to longer growth period in the respective sowing time and variety. During emergence all genotypes availed same number of GDD. Comparatively longer duration of each respective phenophase and total growth duration of the crop in the respective sowing time and variety cause higher rate of accumulated GDD. According to Agarwal and Gupta (1996) variety Gaurav needed more growing degree day for maturity than variety Durga.

\section{Heliothermal units (HTU)}

The heliothermal units (HTU) accumulated by the crop during different phenophase is shown in Table 2. The $14^{\text {th }}$ July sown crop $\left(D_{3}-28\right.$ MW) had highest accumulated HTU $\left(7324{ }^{0} \mathrm{C}\right.$ day hrs) this was due to comparatively more sunshine hours across end phase of $\mathrm{D}_{3}$ sowing.

It was followed by $\mathrm{D}_{4}, \mathrm{D}_{2}$ and $\mathrm{D}_{1}$. This was mainly due to more number of sunshine hours available across seed formation to seed development stage in later sown crops. Dhingra et al., (1995) reported that the crops sown on $5^{\text {th }}$ June accumulated maximum number of heliothermal units which reduce consistently with each delay in sowing.

Among the cultivars, the highest heliothermal units $\left(7374{ }^{0} \mathrm{C}\right.$ day) were observed in TAMS98-21 followed by JS-335 and JS-9305.

Accumulation of higher HTU was primarily due to comparatively longer growth duration of crop coupled with greater sunshine hours in the respective sowing date and for the respective genotype was high accumulation of HTU. Sudha and Latha. 2016 reported that among the varieties the highest HTU required to reach maturity were noted in JS 97-52 as compared to JS-335 and JS- 9305 during both the crop season.

\section{Photothermal units (PTU)}

The accumulated PTU for attaining different phonological stages in soybean have been shown in Table 2. It was observed that different sowing time had marked influence on photo-thermal accumulation. Sowing of 26 MW $\left(\mathrm{D}_{1}\right)$ availed maximum photo-thermal units $\left(20392{ }^{0} \mathrm{C}\right.$ day $\left.\mathrm{hr}\right)$ under all the varieties and it decreased with each later sowings $\left(\mathrm{D}_{2}\right.$ to $\mathrm{D}_{4}$ ). In fact earlier sown crops required more PTU to complete different phenological stages. 
Table.1 Rainfall distribution (mm) among various phenophase of soybean cultivars under different sowing time

\begin{tabular}{|l|}
\multicolumn{1}{|c|}{ Phenophase } \\
\hline Vegetative stage \\
\hline Flowering \\
\hline Pod formation to full seed development \\
\hline Maturity \\
\hline Total \\
\hline Vegetative stage \\
\hline Flowering \\
\hline Pod formation to full seed development \\
\hline Maturity \\
\hline Total \\
\hline Vegetative stage \\
\hline Flowering \\
\hline Pod formation to full seed development \\
\hline Maturity \\
\hline Total \\
\hline Vegetative stage \\
\hline Flowering \\
\hline Pod formation to full seed development \\
\hline Maturity \\
\hline Total \\
\hline Vegetative stage \\
\hline Flowering \\
\hline Pod formation to full seed development \\
\hline Maturity \\
\hline Total \\
\hline
\end{tabular}

\begin{tabular}{|c|c|c|c|}
\hline JS-335 & JS-9305 & TAMS-98-21 & Mean \\
\hline \multicolumn{4}{|c|}{$D_{1}-26 \mathrm{MW}(28.06 .2016)$} \\
\hline 495.3 & 487.5 & 495.3 & 492.7 \\
\hline 2.7 & 10.5 & 6.1 & 6.4 \\
\hline 141.6 & 103.7 & 140 & 128.4 \\
\hline 4.4 & 39.7 & 61.5 & 35.2 \\
\hline 644.0 & 641.4 & 702.9 & 662.8 \\
\hline \multicolumn{4}{|c|}{$\mathrm{D}_{2}-27 \mathrm{MW}(\mathbf{0 5 . 0 7 . 2 0 1 6 )}$} \\
\hline 420.9 & 420.9 & 420.9 & 420.9 \\
\hline 13.7 & 3.4 & 13.7 & 10.3 \\
\hline 129.7 & 140 & 170.2 & 146.6 \\
\hline 61.5 & 40.5 & 50 & 50.7 \\
\hline 625.8 & 604.8 & 654.8 & 628.5 \\
\hline \multicolumn{4}{|c|}{$\mathrm{D}_{3}-28 \mathrm{MW}(14.07 .2016)$} \\
\hline 188.7 & 188.7 & 192.1 & 189.833 \\
\hline 15.2 & 13.7 & 16.8 & 15.2 \\
\hline 188.9 & 170.2 & 184.7 & 181.3 \\
\hline 29.8 & 50 & 29 & 36.3 \\
\hline 422.6 & 422.6 & 422.6 & 422.6 \\
\hline \multicolumn{4}{|c|}{$D_{4}-29 M W(14.07 .2016)$} \\
\hline 194.2 & 194.2 & 194.2 & 194.2 \\
\hline 6.5 & 6.5 & 7.2 & 6.7 \\
\hline 184.7 & 184.7 & 213 & 194.1 \\
\hline 29 & 29 & 0 & 19.3 \\
\hline 414.4 & 414.4 & 414.4 & 414.4 \\
\hline \multicolumn{4}{|c|}{ Mean } \\
\hline 324.8 & 322.8 & 325.6 & 324.408 \\
\hline 9.5 & 8.5 & 11.0 & 9.7 \\
\hline 161.2 & 149.7 & 177.0 & 162.6 \\
\hline 31.2 & 39.8 & 35.1 & 35.4 \\
\hline 526.7 & 520.8 & 548.7 & 532.1 \\
\hline
\end{tabular}

Table.2 Accumulated GDD, accumulated HTU, photo thermal units and heat use efficiency of seed and biomass of soybean varieties under different sowing time

\begin{tabular}{|c|c|c|c|c|c|}
\hline \multirow[t]{3}{*}{ Treatments } & \multirow{3}{*}{$\begin{array}{c}\text { GDD } \\
\left({ }^{\circ} \mathrm{C} \text { day }\right)\end{array}$} & \multirow{3}{*}{$\begin{array}{c}\text { Accumulated } \\
\text { HTU } \\
\left({ }^{0} \mathrm{C} \text { day hr }\right)\end{array}$} & \multirow{3}{*}{$\begin{array}{c}\text { Photothermal } \\
\text { units } \\
\left({ }^{0} \mathrm{C} \text { day hr) }\right.\end{array}$} & \multicolumn{2}{|c|}{ Heat use efficiency } \\
\hline & & & & Seed & Biomass \\
\hline & & & & \multicolumn{2}{|c|}{$\left(\mathrm{Kg} \mathrm{ha}^{-10} \mathrm{Cday}^{-1}\right)$} \\
\hline \multicolumn{6}{|l|}{ Sowing date } \\
\hline$D_{1}-26$ MW (28 June) & 1653 & 6610 & 20392 & 1.43 & 2.95 \\
\hline $\mathrm{D}_{2}-27 \mathrm{MW}$ (05 July) & 1608 & 6927 & 19657 & 1.37 & 2.82 \\
\hline $\mathrm{D}_{3}-28 \mathrm{MW}$ (14 July) & 1546 & 7324 & 18701 & 0.99 & 2.33 \\
\hline $\mathrm{D}_{4}-28 \mathrm{MW}$ (20 July) & 1478 & 7112 & 17739 & 0.94 & 2.30 \\
\hline \multicolumn{6}{|l|}{ Variety } \\
\hline$V_{1}-$ JS-335 & 1568 & 6958 & 19082 & 1.58 & 2.64 \\
\hline$V_{2}-J S-9305$ & 1523 & 6647 & 18572 & 1.25 & 2.54 \\
\hline$V_{3}-$ TAMS-98-21 & 1624 & 7374 & 19713 & 1.02 & 2.61 \\
\hline
\end{tabular}


Table.3 Seed yield, total biomass yield, and water use indices of soybean varieties under different sowing time

\begin{tabular}{|c|c|c|c|c|}
\hline Treatment & $\begin{array}{c}\text { Seed yield } \\
\left(\mathrm{kg} \mathrm{ha}^{-1}\right)\end{array}$ & $\begin{array}{l}\text { Total biomass } \\
\text { yield }\left(\mathrm{kg} \mathrm{ha}^{-1}\right)\end{array}$ & Eta $(\mathrm{mm})$ & $\begin{array}{c}\text { WP } \\
\left(\mathrm{kg} \mathrm{ha-mm}^{-1}\right)\end{array}$ \\
\hline \multicolumn{5}{|l|}{ Sowing date } \\
\hline $\mathrm{D}_{1}-26 \mathrm{MW}$ (28 June) & 2359 & 4871 & 328.3 & 7.19 \\
\hline $\mathrm{D}_{2}-27 \mathrm{MW}$ (05 July) & 2189 & 4529 & 307.4 & 7.13 \\
\hline $\mathrm{D}_{3}-28 \mathrm{MW}$ (14 July) & 1531 & 3608 & 291.3 & 5.26 \\
\hline $\mathrm{D}_{4}-28 \mathrm{MW}$ (20 July) & 1383 & 3397 & 275.1 & 5.03 \\
\hline $\mathrm{SE}(\mathrm{m}) \pm$ & 62 & 121 & & \\
\hline $\mathrm{CD}(\mathrm{P}=0.05)$ & 179 & 350 & & \\
\hline \multicolumn{5}{|l|}{ Variety } \\
\hline $\mathrm{V}_{1}-\mathrm{JS}-335$ & 2021 & 4163 & 300.1 & 6.66 \\
\hline $\mathrm{V}_{2}-\mathrm{JS}-9305$ & 1911 & 3876 & 297.9 & 6.34 \\
\hline $\mathrm{V}_{3}$ - TAMS-98-21 & 1665 & 4265 & 303.6 & 5.45 \\
\hline $\mathrm{SE} \mathrm{m} \pm$ & 54 & 105 & & \\
\hline $\mathrm{CD}(\mathrm{P}=0.05)$ & 155 & 303 & & \\
\hline \multicolumn{5}{|l|}{ Interaction } \\
\hline $\mathrm{SE} \mathrm{m} \pm$ & 108 & 210 & & \\
\hline $\mathrm{CD}(\mathrm{P}=0.05)$ & NS & NS & & \\
\hline CV\% & 12 & 10 & & \\
\hline
\end{tabular}

\section{Rainfall Distribution}

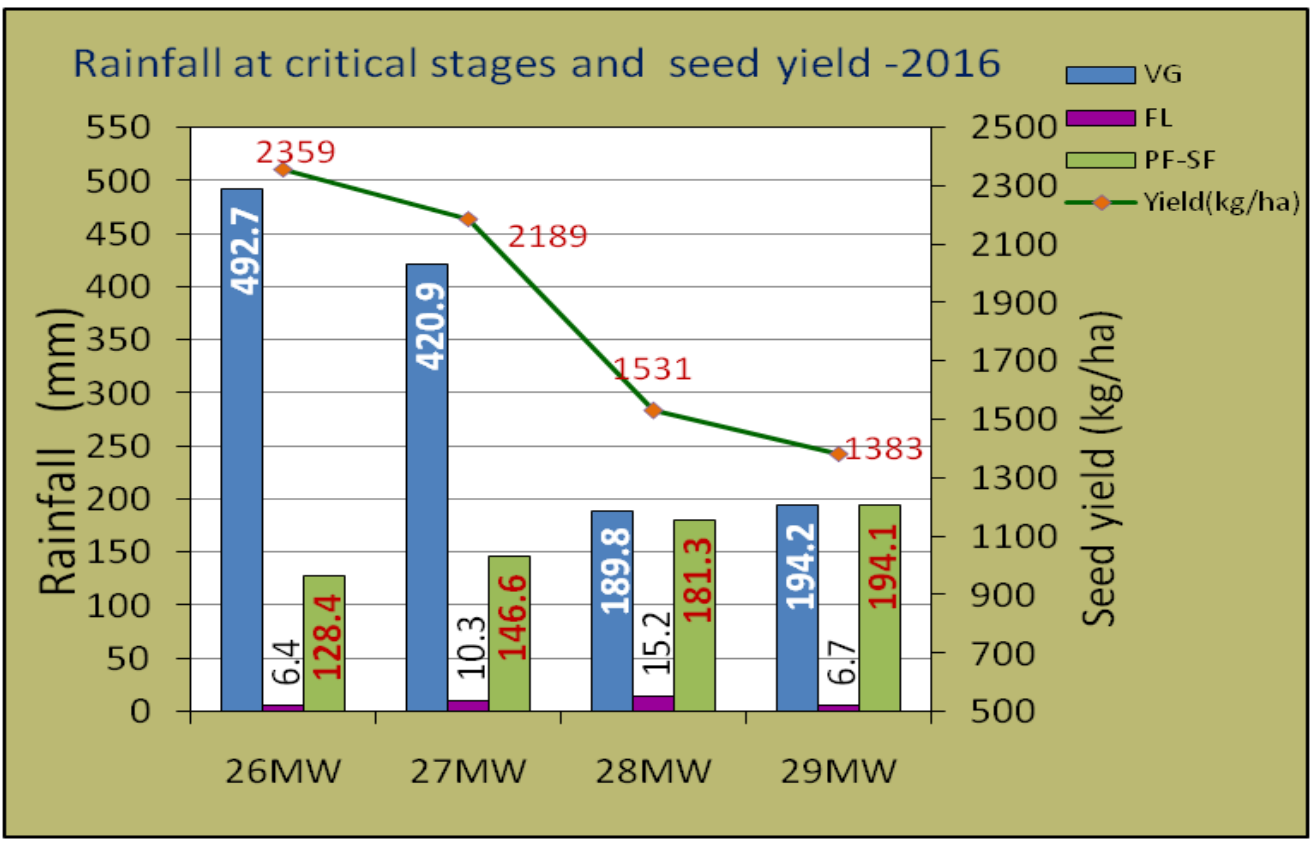




\section{Day length hours}

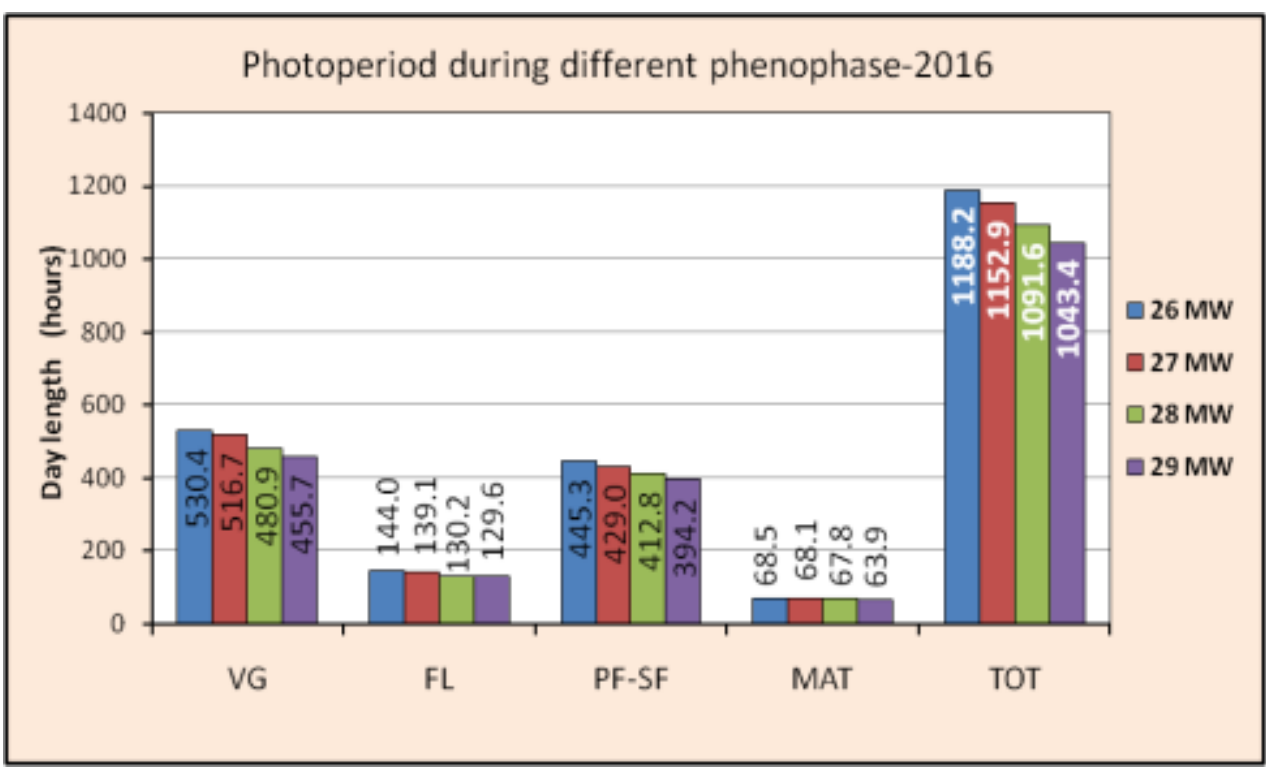

Heat use efficiency

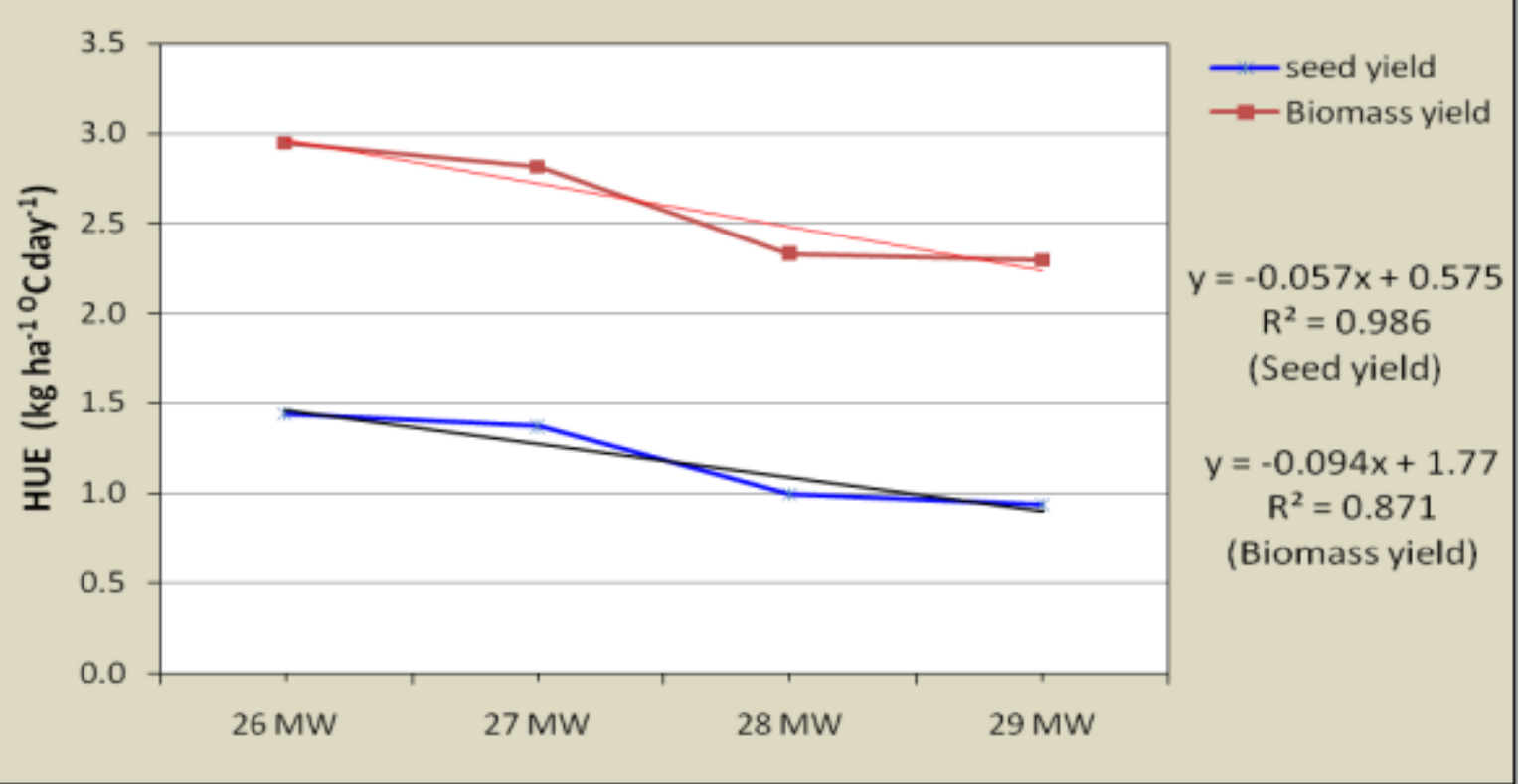

Sudha and Latha 2016 reported that highest accumulated value of the PTU experience by the crop during sowing maturity in the early sowing (24405 and $24490{ }^{\circ} \mathrm{C}$ day) followed by second sowing $\left(22489\right.$ and $20847^{\circ} \mathrm{C}$ day) and third sowing date $\left(18634\right.$ and $18843{ }^{\circ} \mathrm{C}$ day) during both year under study.
Among the cultivars, TAMS98-21 required more PTU to complete different phenological stages and consumed the highest cumulative PTU $\left(19713{ }^{\circ} \mathrm{C}\right.$ day hr) followed by JS-335 $\left(19082{ }^{\circ} \mathrm{C}\right.$ day hr) and JS-9305 $\left(18572{ }^{\circ} \mathrm{C}\right.$ day $\mathrm{hr}$ ). Accumulation of higher photothermal units was due to longer growth period and 
photoperiod phenophase and total in earlier sowings compared to later sowings. Comparatively longer duration of each respective phenophase and total growth duration of the crop in the respective sowing time and variety caused higher accumulation of GDD and consequently higher photothermal units. The results are in confirmation with the findings of Sudha and Latha (2016) reported that as regards the three varieties viz. JS-335, JS-9305 and JS-97-52 the variety JS 93-05 accumulated lowest value of PTU whereas JS 97-52 accumulated highest PTU.

\section{Day length hours}

Day length, temperature and rainfall are the most important climatic factors to select a region for specific crop cultivation and production. Day length hours (sunrise to sunset hours) across different phenophase of soybean under different dates of sowing are indicated graphically.

Soybean crop encountered maximum day length hours for each of the phenophase under $26 \mathrm{MW}$ sowing $\left(\mathrm{D}_{1}\right)$ and day length hours encountered for each phenophase decreased with later sowings $\left(D_{2}\right.$ to $\left.D_{4}\right)$. Similarly, day length hours decreased gradually across each subsequent phenophase of soybean crop. Longer day length hours in earlier sowings caused extended duration of vegetative period as well as reproductive stages as compared to later sowings. Hence, the later sown soybeans progressed comparatively faster through the respective phenological stages and ultimately reduced the plant cycle causing the plant to yield less than its full potential. The relative length of the light and dark periods affects the production of carbohydrates by all crops. In order to cope with night time darkness, plants during the day allocate part of their photosynthates for storage, often as starch. This stored reserve is then degraded at night to sustain metabolism and growth. Hence, darker period demands more allocation of photosynthates to sustain metabolism and growth reducing the share for growth and development. Nabi Khaliliaqdam (2014) recorded similar results and reported that the delay in sowing date, days to flowering and days to pod initiation decreased along with decrease in photoperiod.

\section{Heat use efficiency}

Heat use efficiency (Table 2) with respect to seed yield and biomass (seed + straw) production under different dates of sowing and in different varieties of soybean crop showed that heat use efficiency $\left(\mathrm{kg} \mathrm{ha}^{-1}{ }^{\mathrm{O}} \mathrm{C}\right.$ day $^{-1}$ ) in terms of seed yield and biomass production was higher under $\mathrm{D}_{1}(26 \mathrm{MW})$ sowing followed by $\mathrm{D}_{2}, \mathrm{D}_{3}$ and $\mathrm{D}_{4}$. The least heat use efficiency was under $29^{\text {th }} \mathrm{MW}$ sowing $\left(\mathrm{D}_{4}\right)$. Balkrishnan and Natrajaratnam (1986) and Mahajan et al., (1993) revealed that heat use efficiency was higher in $21^{\text {st }}$ February than in $21^{\text {st }}$ September sowing. Also reported that seed yield had positive and significant association with heat units availed at flowering and harvest stage. Sudha and Latha (2016) recorded that HUE was highest for first week of sowing followed third week of July and lowest HUE was recorded under August sown crop.

Similarly, HUE with respect to seed and biomass yield was maximum in variety JS335. It was followed by JS 9305 in terms of seed yield and TAMS 98-21 in terms of biomass yield. HUE with respect to biomass production was higher in variety TAMS 9821. The lowest HUE $\left(0.88 \mathrm{~kg} \mathrm{ha}^{-1}{ }^{\mathrm{O}} \mathrm{Cday}^{-1}\right)$ in terms of seed yield was under $\mathrm{D}_{4}(29 \mathrm{MW})$ sowing with TAMS 9821 and for biomass yield it was lowest $\left(2.22 \mathrm{~kg} \mathrm{ha}^{-1}{ }^{\mathrm{O}} \mathrm{C}\right.$ day $)$ under $\mathrm{D}_{4}(29 \mathrm{MW})$ sowing with JS-9305. Hundal et al., (2003) reported that cv. SL-295 recorded higher heat use efficiency for both 
dry matter and seed yield than the cultivar PK-416. Sudha and Latha (2016) recorded that among the varieties highest HUE were noted in JS 97-52 followed by JS 335 and lowest HUE in JS 93-05 during both year of crop season.

\section{Productivity}

Crop sown during $26^{\text {th }} \mathrm{MW}\left(\mathrm{D}_{1} 28\right.$ June) recorded significantly higher seed and biomass (seed + straw) yield and it was followed by $27^{\text {th }} \mathrm{MW}\left(\mathrm{D}_{2} 5^{\text {th }}\right.$ July) sowing both in respect of seed yield and biomass yield, being statistically at par (Table 3). Crop sown on $20^{\text {th }}$ July $(29 \mathrm{MW})$ recorded the lowest seed and biomass yields. The higher yield level achieved by $26^{\text {th }} \mathrm{MW}$ (28 $8^{\text {th }}$ June) sowing was due to occurrence of adequate rainfall (moisture) across vegetative and reproductive period stress, and comparatively favourable thermal regimes and photoperiod across the vegetative and reproductive phase of the crop as compared to remaining sowings. Further delayed sowings exposed the crop to lower soil moisture regime during vegetative growth period this year, and comparatively lower photoperiod phenophase wise particularly across critical phases of pod formation and seed development. Matsul and Nishiiri (1982) reported that delay in sowing reduced dry matter per plant.

Walab et al., (1984) found that soybean cv. Clark sown on April $26^{\text {th }}$ gave higher yield, heavier fresh pod weight and higher number of dry seeds pod $^{-1}$ compared to late sowing (15 ${ }^{\text {th }}$ June) under Egypt conditions. Anil Kumar et al., (2008) reported that early sown soybean crop (16 $\left.{ }^{\text {th }} \mathrm{June}\right)$ produced more drymatter and also resulted in higher seed yield and stover than late sown crop as they are availed more growing degree days. Results are in confirmatively with Mengxuan $\mathrm{Hu}$ and Pawel Wiatrak (2011) and Kathmale et al., (2013).
Though bright sunshine hours encountered were more towards end phase in later sowings however, limited expression of inherent potential growth and development in later sowings might have limited its use efficiency. Secondly, the shortening of the duration of various growth phases in the late sown crop might be the probable reason of the reduction in total biomass production. Results are in line with the findings of Barik and Sahu (1989) and Kathmale et al., (2013).

Among the varieties, JS-335 recorded significantly higher seed yield than TAMS 98-21, however it was statistically at par with JS-9305. Variety JS-9305 also recorded significantly more seed yield over TAMS 9821. As regards biomass yield TAMS 98-21 being statistically at par with JS-335 yielded significantly higher biomass than JS-9305. Interaction effect (sowing date $\mathrm{x}$ varieties) was found to be non-significant in respect of seed yield and biological yield. Bhatia et al., (1999) observe that seed yields decrease with delay in sowing and varieties JS-335, NRC-2 and JS-71-05 gave the highest yields. Billore et al., (2000) revealed that significantly higher number of pods plant ${ }^{-1}$ and significantly higher seed yield were observed with the variety Ahilya-3 compared to JS-335, JS 71-05 and PK 472.

\section{Water use}

Different water use indices across the total growing period of soybean as influenced by different treatments are indicated in Table 2. Actual water use (Eta) decreased with later sowings. Water productivity (WP), as a ratio of yield to actual crop water use was, maximum under $26 \mathrm{MW}$ sowing $\left(\mathrm{D}_{1}\right)$ and decreased with later sowings. Among the varieties, TAMS-98-21 showed higher Eta followed by JS-335and JS-9305. WP was higher with JS-335 followed by JS-9305 and TAMS-98-21. 
Thus it may be concluded that, soybean sown during $26^{\text {th }} \mathrm{MW}$ recorded significantly higher seed yield with maximum heat use efficiency and water use efficiency. Soybean variety JS 335recorded significantly higher seed yield with maximum heat use efficiency and water use efficiency. Pod formation to seed fill stage is the most important for determining the quantity of seed yield. During these stages, minimum temperature, rainfall and relative humidity (RH I \& II) showed a positive and significant association with the seed yield.

\section{References}

Agrawal U.S. and Gupta V.K. 1996. Heat unit requirement of rainfed soybean (Glycine max). Ind. Jour. of Agric. Sci. 66 (7): 401-404.

Anil Kumar, V. Pandey, A.M. Sheikh and Manoj Kumar. 2008. Evaluation of Crop Agro-Soybean (Glycine max (L) Merill) model under varying environmental condition. American Eurasian. J. Agron. 1(2): 34-40.

Anil Kumar, V. Pandey, A.M. Sheikh and Manoj Kumar. 2008. Growth and yield response of soybean in relation to temperature, photoperiod and sunshine duration at Anand (Gujrat) India. American Eurasian J. Agron. 1(2): 4550.

Balkrishnan, K and Natarajaratnam. 1986. Heat use efficiency in Pigeonpea. Madras Agriculture Journal. 73:101104.

Barik T. and Sahoo K.C.1989. Response of soybean to date of sowing and spacing. Ind. Jour. of Agron. 34(4): 464-466.

Bhatia V.B., S.P. Tiwari, and O.P. Joshi. 1999. Yield and its attributes as affected by planting dates in soybean varieties. Ind. Jour. of Agric. Sci. 69 (10): 696699.
Billore S.D, Joshi O.P, and Ramesh A. 2000. Performance of soybean genotypes on different sowing dates and close spacing in Vertisols. Ind. Jour. of Agric. Sci. 70 (9):577-580.

Dhingra K.K, Kaur H., Dhalivalival L.K, and Singh J.1995. Phenological behaviour and heat unit requirement of soybean genotypes under different date of sowing. Journal of Research, Punjab Agriculture University, 32(1): 129-135.

Hundal S.S., Singh H. Kaur P and Dhaliwal L.K. 2003. Agroclimatic models for growth and yield of soybean (Glycine $\max$ ). Ind. Jour. of Agric. Sci. 7 (12): 668-670.

Kathmale, D.K., Andale, U. and Deshmukh, M.P. 2013. Growth and yield of soybean genotypes as influenced by sowing time at different locations under climate change situation in Maharashtra. International Journals of Bio-Resource and Stress Management. 4(4):492-495

Mahajan, C.R., S.H. Mehetre and P.A. Patil. 1998. Association of morphological stress with yield in soybean (Glycine max). Ann. Physiol. 7(1): 131-133.

Matsul, S. and K. Nishiiri. 1982. Effect of planting date on yield of soybean in hokkiads II compensation for yield decrease due to late planting by increase plant population. Field crops Abstract 35(10):814-817.

Medidia, S.K., Diwan Singh, and Surender Singh. 2006. Effect of sowing dates on agrometerological indices of soybean. Annals of Biology 22 (1):49-51.

Mengxuan, Hu. and Pawel Wiatrak. 2011. Effect of planting date on soybean growth, yield and grain quality: Review. Agron J. 104 (3): 785-790.

Nabi Khaliliaqdam. 2014. Determination of sensitive growth stages of soybean to photoperiod. Agric. sci. dev., Vol (3), No (4), April, 2014. pp. 140-145 
Singh R.V and Arya M.P.S. 1994. Crop weather relationship in rainfed soybean (Glycine max). Ind. Jour. of Agron. 39(1): 133-136.

Sudha A. and P. Latha 2016. Growth and yield Response of Soybean (Glycine $\max$ L.) in Relation to Temperature, Photoperiod and Sunshine Duration. International Journal of Recent Innovation in Engineering and Research $1(3): 1-4$.

\section{How to cite this article:}

Karunakar, A.P., M.B. Nagdeve, A.B. Turkhede and Mali, R.S. 2018. Agro-Meteorological Indices for Soybean Crop under Different Growing Environment. Int.J.Curr.Microbiol.App.Sci. 7(08): 4617-4627. doi: https://doi.org/10.20546/ijcmas.2018.708.487 